\title{
Conflict between Villages \\ (Case Study of Conflict between Beka Village and Binangga Marawola District Sigi Regency)
}

\author{
Adam Adam ${ }^{1}$, Saude Saude ${ }^{2}$, Malkan Malkan ${ }^{3}$, Rustina Rustina ${ }^{4}$ \\ \{adamiainpalu05@gmail.com ${ }^{1}$, saude@iainpalu.ac.id ${ }^{2}$, malkanmannan@gmail.com ${ }^{3}$, \\ rustinaftik@gmail.com ${ }^{4}$ \} \\ Institut Agama Islam Negeri (IAIN) Palu, Indonesia ${ }^{1}$, Institut Agama Islam Negeri (IAIN) Palu, \\ Indonesia ${ }^{2}$, Institut Agama Islam Negeri (IAIN) Palu, Indonesia ${ }^{3}$, Institut Agama Islam Negeri (IAIN) \\ Palu, Indonesia ${ }^{4}$
}

\begin{abstract}
Conflict is part of human avoidance. Various forms of conflict appear in human life one of them is a conflict between villages. The conflict between villages is crowded in parts of Eastern Indonesia, mainly in Sigi regency. Almost all the villages in Sigi district have conflicted. The conflict sometimes recurred between one village and another. One of the worst conflicts is the conflict between Beka Village and Desa Binangga. This conflict was sparked by a fight between high school students at his school and outside the school. This conflict is also triggered by the absence of children who are drunk, like to detain people in the middle of the street and treat people harshly. These two factors trigger a conflict and then process it into a large one. The factors that exacerbate this conflict are youth delinquency, media factors, political factors, village prestige factors, and economic factors. The resolution of the conflict has been carried out repeatedly so that the two village sagaincoexist in a state of peace.
\end{abstract}

Keywords: Conflict, Between Villages, Factors

\section{Introduction}

\subsection{Background Issues}

The phenomenon of conflict in Indonesia has been increasingly rife lately, the conflict is behind religious factors, ethnic factors, and also natural resource grabbing factors.

The conflict that is the source of The Religion in [1] in Poso, namely the conflict between Christianity and Islam. This religious conflict occurred again in Mataram which was examined [2], and this religious conflict occurred also in Kupang which was swallowed [3].

This conflict research was also conducted by researchers in the field of conflict as done [4], this political conflict is also examined, namely conflict due to the suppression of the region. This conflict has also been examined [5], a conflict between Dayak and Madura ethnic groups.

Among these studies, there has not been a specific study of conflict between villages, whereas conflict between villages is also part of the conflict that needs to be a concern. Moreover, in Central Sulawesi, the conflict between villages is an interesting conflict researched, a conflict between villages such as an arisan (gathering) activity. The conflict moved from one village to another, and even the conflicts continued to repeat in each of them. 
Villages that conflict in Central Sulawesi include Binangga Village with Padende Village, Binangga Village with Beka Village, Rindau Village with Tulo Village, Tatura with Marawola, Nunu with Tawanjuka, and there is even a conflict between hamlets in one village in Pombewe Village.

According to Alam Sriyanto (interview, dated January 9, 2012) that specifically the conflict of Beka village and Binangga is long. The conflict began in the 1980s, after which it was processed to this day. The conflict in the 1980s was a minor conflict among young people only. Usually every time there is a crowd like a wedding party in another village, then young children from Beka village fight with young people from Binangga Village. It keeps repeating itself, and it usually takes revenge at some point in retaliation. This conflict continues to result in a larger conflict involving village identity, namely village prestige or village self-esteem. Each feels right and doesn't want to be blamed. They formed village solidarity and even dragged other villages out of the solidarity of families in other villages so that the conflict seeped into other villages. And a larger manifest conflict occurred in late 2012 in November and December. As a result of this conflict, about 20 homes were burned, one person died and dozens were injured.

During the conflict, there has been peace initiated by the Governor, Kapolda, and Regent of Sigi. This was done after the burning of five houses in Beka Village carried out by Binangga Village. And after that a re-emerged conflict that was even greater, where Binangga Village attacked Padende Village, as many as 15 houses were burned down. After that, they tense and concentrate on each other and confront each other. And finally, the conflict is getting worse, but the grudge, mutual suspicion is always there, of course, the potential for conflict is always there. The hard and long of this conflict is of course some factors affect it. And to reveal conflict, conflict dynamics, factors that influence conflict, and conflict resolution, the research team will explore it in a further scientific study.

\subsection{Problem Statement}

Based on the background description of the above problem, the formulation of the problem in this study is as follows: (1) What are the dynamics of the conflict between Beka Village and Binangga Marawola District of Sigi Regency (2)What factors influence the conflict between Beka Village and Binangga Marawola District of Sigi Regency (3)What conflict resolution between Beka Village and Binangga Marawola District of Sigi Regency?

\subsection{Research Objectives}

The objectives of the research in this discussion are as follows: (1)Describes the dynamics of conflict between Beka Village and Binangga Marawola Sub-District of Sigi Regency (2)Analyze the factors that influence the conflict between Beka Village and Binangga Marawola District of Sigi Regency (3)Describes conflict resolution between Beka Village and Binangga Marawola District of Sigi Regency.

\section{Literature Review}

\subsection{Sociological Perspective on Conflict}

Conflict theory is a paradigm with a theory of structural functionalism, but even though one paradigm, conflict theory is precisely built to directly oppose the theory of structural 
functionalism. What is less noticed by adherents of structural functionalism, is precisely the center of attention of the adherents of conflict theory.

As with the flow of structural functionalism, some figures support it with their views, hence the flow of conflict as well. The flow of conflict has its thinkers as follows:

The first conflicting figure was Karl Marx. According to Karl Marx, "the main perpetrators of social change are not certain individuals, but rather social classes, therefore we can only understand history with all the developments that occur when we pay attention to the social classes in the society concerned, which should be noticed not only what kind of class is found, but how the power structure among them. According to Marx, it would appear that in every society there are powerful classes and classes controlled by Marx [6].

The second conflicting figure is Georg Simmel. Georg Simmel saw the conflict as a symptom that was impossible to avoid in society but played a positive role in maintaining social and fostering a sense of unity. Simmel disagrees to see social structure as a system that is only divided into two strata, which is seen as a mixed and dissociative process that cannot be separated from each other. Separation can only be done in the level of analysis, not at the level of reality [7].

The third person from conflict theory is Lewis A. Coser. Lewis A Coser is a sociologist who focuses on the functions of conflict in social life. Coser's ideas were the development of Simmel'sideas. His famous book was The Functions of Social Conflict in 1964.According to [8], conflict is not always a negative thing, but conflict also has positive functions. Conflict can be an instrumental process in the formation of statements and maintenance of social structures. Conflicts can place and maintain a boundary between two or more groups. Conflict with other groups can strengthen the group's identity and protect it from melting into the social world around it.

The fourth conflicting figure is Johan Galtung. According to Johan Galtung, implicitly the predecessors of social sciences such as Marx, Weber, Durkheim, and Hobbes, showed violence emerging on an individual and State scale. Violence as a result of rational calculations mainly affects the concept of organized violence, namely violence in social movements. The concept of violence of conflict sociological scientists is presented as a representation of individuals and countries later developed by Johan Galtung [9].

\section{Methods}

This type of research is descriptive in describing an event in words without statistical tests. And the approach used is qualitative. Qualitative research is a study that uses a scientific background, intending to interpret phenomena that occur and are carried out by way of engaging with various existing methods. With various characteristics owned [10].

The model or design of the research used is the phenomenological model. Phenomenology is a study that describes the use based on the life experiences of several individuals to an event. Phenomenology essentially seeks to explore the structure of awareness through the experience of human life [11].

The data collection techniques used are observation, interview, and documentation, namely extending the participation of research, the persistence of observation, and triangulation. And finally, the data analysis technique used is the phenomenological data analysis technique ed by Creswell. 


\section{Results and Discussion}

\subsection{Conflict Dynamics between Beka and Binangga Village Marawola Sub-District}

The conflict between Beka village and Binanggga village is long in history, this conflict was screened from a small one then processed into a large open conflict in 2012.The dynamics of the conflict of Beka village and Binangga village process are divided into several stages.

In the first stage, namely in the 1980s, in the 1980s the conflict that occurred was a small brawl between the youths of Beka and Binangga at every wedding or other crowd. It holds a grudge of resentment. This conflict is processed from year to year. Those grudges will be kept and at some point want to be avenged. Old events will be recalled, these grudges are like neatly stored and piled up explosives, which at some point are ready to be detonated. It's just waiting time and where's the right moment. The fires of conflict extension from day to day, from week to week, from month to month, and from year to year are growing and at one point detonation of explosives that have been stored neatly and stacked between the two villages is a grudge or resentment. (Alam Sriyanto, interview, 4-11-2014).

The second stage, which is the activity of school children who often fight in their school and outside the school in SMAN 1 Marawola which is located in the sub-district town located in Binangga village. Children often fight, fights carry village names, often Binangga children hit the school children of SMAN 1 Marawola and different villages with them. These children took revenge, they told each other about the treatment of the school children in Binangga. These people sometimes confront each other. Besides, there are activities of young people in Binangga village who are drunk on the side of the road then detain passers-by while asking for cigarettes and money, to every passer-by. Passers-by who are different villages with them are often targeted to be held and held. They are asked for cigarettes and money, if there is nothing they treat it disrespectfully and even at the time, the people who are treated like that do not accept it and hold a grudge. These grudges are stored neatly in their memory at some point in avenge (Mahfud, interview, 5-11-2014).

The third stage, an open conflict involving village prestige or village self-esteem. The open conflict between the villages began with the number of schoolchildren fighting and fighting in each of the villages that their teachers were slow to deal with. Finally, the village children who were hit were united against the children of Binangga village. They were attacked, this conflict was resolved by the police who immediately brought to the governor to be completed through the police. The conflict subsided because it was quickly handled by the police with the governor and the police.

The conflict opened again, erupting a few months later. Where the trigger is the issue of immorality, where a couple passing by in Binangga village is bullied by a young man, his wife is held and squeezes her chest, then in the hold of her penis. The couple reported it to the police, but the police didn't take it seriously because according to the police there was not enough evidence, no witnesses saw the incident, the culprit was clear but there were no eyewitnesses, eventually the matter was blurred. It just so happens that a victim is a man from Bekavillage. Wants community was appointed the culprit and processed. The community was irritated and angry that there was a massive attack by various villages in Binangga village, which carried out ranging from beka village, Padende, Porame, Palane, Kaleke, and other neighboring villages, 5 houses burned and 1 person died from tear gas spray from the police. The conflict erupted after being handled by the police along with Danrem and the Governor. All Brimob from Manado, Parigi, Poso, Makassar, and Palu was brought in to secure the situation, the Regents and Local Governments all intervened so that finally the situation was safe again as it was. 
Three months of conflict erupted again. The conflict was triggered by the beating of a brick-loading driver in Binangga Village, who happened to be from Beka Village, beka villagers could not accept Binangga village's treatment of its citizens. The incident happened on Friday morning in 2012. Finally on Friday night of beka villagers attacked Binangga village, three houses burned, many injured and one person died, against this conflict in the rearrival of Brimob from Kelapa Dua and with Brimob from various areas both in Manado, Parigi, Makassar, and Palu to secure the situation.

\subsection{Factors Influencing the Conflict between Beka Village and Binangga Village}

The conflict between Beka village and Binangga village became violent and long due to the many factors that supported it. The factors that make the conflict hard and the length of the conflict as follows:

\subsubsection{The Mischief of Young People}

This juvenile mischief became the main source of conflict between Beka village and Binangga village, where students love to fight at their school, they hold each other back and enter into open conflict. And the young people who are drunk on the side of the road, detaining and trampling people. They force people to give money with them, and sometimes they also commit immoral acts that treat women in violation of religious and cultural norms. They held the women's belongings and even the wife of the man in front of her husband. This provokes a burning grudge and wants to be avenged in the next day. The behavior of these young men has crossed the boundaries of propriety and violated religious and cultural values. This is all a potential source of conflict, between the two village's beka and Binangga villages.

\subsubsection{Media Factors}

Media factors also accelerate and exacerbate existing conflicts. Through Mobile they are very quick to format and capture that information sometimes cannot be held accountable. Slanders through that information often occur. Finally they suspect each other, heat each other up so that between them enter into an open conflict, which cannot be avoided, the worst conflict occurred in November and December 2012.It is the role of the media to make the severe and long conflict in Beka village and Binangga village become a reality, so the media is one of the factors so that the conflict between Beka village and Binangga village.

\subsubsection{Political Factors}

In the conflict between Beka village and Binangga this is a factor that makes the conflict occur and long due to political factors. At that time the Camat and regent wanted to be put aside because he was considered incapable of handling the conflict. Certain people want to be path cloud, even the blatantly says that he's a Regent not like this conflict. There was a desire to create an old conflict situation so it seemed that the local government of both the Camat and the Regent was unable to handle the existing conflict so it was natural to be replaced, so this conflict was hard and long because there was also a political charge. 


\subsubsection{Village Prestige Factor or Village Self-Esteem}

The conflict between Beka and Binangga villages takes long because it wanted to win the pride of the village or the prestige of the village. Each village feels ashamed and they desperately find la self-esteem and the prestige of the village is mainly in the wishes of young people. The young men will unite and work together to defend the self-esteem of the village. For the sake of the self-esteem of his village, they are willing to sacrifice their energy, materials, and even their life. They make weapons assemblies at great expense to fight me 1 cloud neigh boring villages. It's all because I want to give me the self-esteem of his community, everything I'm a sacrifice both energy, property, and their lives. It's that aggravates and makes the long conflict between these two villages namely Beka and Binangga.

\subsubsection{Economic Factors}

In the conflict between Beka village and Binangga village is not separated from economic problems, during the existing conflict has required iron and explosives namely matches. Iron and matches were needed to make the assembled weapons and its materials. There are automatically people in this case who are traders and besides in signaling that this conflict is maintained and allowed by the security authorities, because every case that happens in the community, when reported they do not respond quickly and in the process quickly, precisely let it be. So according to the community that this conflict is maintained so that the police can reason to come and long service in the conflict area. It is there a budget that goes down as a security budget, so there is an economic element at play in this conflict. Each conflict of the country issues a large budget as a public security budget in resolving the conflict, the conflict between Beka village and Binangga lama, and hard because of the playing of factors that affect it including economic factors.

\subsection{Conflict Resolution Between Beka and Binangga Villages}

This conflict was resolved by involving community leaders, religious leaders, Regents, Police Chief in Pegombo regent Sigi room, reached an agreement between the conflicting parties with the making of customary law, and built a peace monument in the middle of Beka village and Binangga village namely in Padende village. The monument is a symbol of peace between the villages. That's where the conflict began to subside until now and added to the hashing of customary law. The customary law of agreement of anyone who hits people will be fined IDR.15, 000,000 (fifteen million rupiahs), and anyone who issues harsh words will be fined IDR.5, 000,000 (five million rupiahs).

The peace deal and customary law were reaffirmed by the governor's government to shoot in place if anyone started the conflict. The governor directly faces the resident Pto asks the authorities to resolve the conflict with a firing order in place. So come out of the emergency law on conflict and the storage of firearms assemblies and the threat of life imprisonment. And in the end, the young men no longer try to disturb each other.

This agreement was followed up by young people by holding local cultural arts activities. The youth themselves held activities pioneered by NKRI 400 personnel and created 1 post of TNI Padende, so that two more years of security runs in the middle of the community. 
Meanwhile, hundreds of assembled weapons and ammunition were seized by residents in Beka itself about 5 carung assembled weapons and so on in Binangga village. The sense of security and peace exists because of the cooperation between the government, community leaders, religious leaders, youth leaders, police, and the TNI, all elements have taken part in creating peace in Marawola sub-district. According to Pallawangi Andifui (interview, 29-102014) said that to resolve the conflict in Marawola sub district, serious efforts have been made by the government along with the community.

Based on the candy No.12 year 2006, the local government has established the Community Early Vigilance Forum (FKDM), this forum is in the form of starting from the district level, sub-district level, and village level. From is facilitated by the local government with the technical agency is KESBANPOL. This forum is in the form of a local government partner. The task of this forum is to detect early information about conflicts that occur in the community. FKDM involves all elements, both community leaders, religious leaders, youth leaders, police, TNI, and local governments starting from regents, camats, and village chiefs. This forum acts as intelligence in the community to detect and report if any seeds of conflict arise. Their work is systematic and co-ordinated with each other.

This forum has been working and the result for a while can see that the conflict between villages has subsided and peace is increasingly intertwined between communities. Hopefully, this sense of peace and security continues in the lives of the people in Marawola Sub-district. And more importantly, is enforcing the law for the perpetrators of the conflict. There are already many young people who are detained by the police by working with the Village Chiefs. Each troubled child is then arrested and handed over to the police. Especially in Beka, 17 people have to live in Selpolice security. Likewise in Binangga there have been many troubled young people to enter Sel as a learning for them. And it turns out that after they came out, they became aware and didn't want to repeat the same thing. Now Beka and Binangga have lived in a peaceful and harmonious atmosphere as it was, and hopefully next as it is.

\section{Conclusion}

Based on the period of lahan and discussion before, then as ampulantherela has follows: (1) The dynamics of the conflict between Beka and Binangga village. The conflict has been processed since the 1980s, where young people often gotolahian every time there are crowded events such as weddings. In2012, the conflict caused victims of both property and human life. (2) Factors that affect the conflict between Beka village and Binangga village namely youth delinquency, media, prestige or village self-esteem, economic, and political factors (3) The resolution of the conflict between Beka village and Binangga village is that this conflict has been held peace by involving all elements of both governments, community leaders, religious figures, youth figures, TNI, and police so that there has been peace and harmony between Beka village and Binangga village in his daily life.

Based on the findings of the authors in the field, it is recommended as follows: (1) The need to eradicate liquor and the like in the community, therefore the main trigger in giving birth to the conflict in the middle of society (2) If anyone starts the problem then it needs to be dealt with immediately and handed over to the authorities so as not to seep into the others (3) The need for law enforcement to anyone guilty. There must be a sense of justice amid the community so that the community is dissed from the prevailing law and law enforcement officers so that the conflict does not repeat itself. (4) The need to maintain good cooperation 
that has been built up over the last two years so that Marawola Sub-district lives in a sense of security and peace, especially in beka and Binangga villages.

\section{References}

[1] Ali, Mursyid.:Konflik sosial bernuansa agama, studi kasus tentang tragedi kerusuhan poso, dalam serial buku konflik sosial bernuansa agama di indonesia". Konflik Sosial Bernuansa Agama di Indonesia. Jakarta: Badan Litbang Agama dan Diklat Keagamaan Puslitbang Kehidupan Beragama Bagian Proyek Peningkatan Pengkajian Kerukunan Hidup Umat Beragama, h. 79-106 (2003)

[2] Halim, Bashori A.: Kasus kerusuhan di mataram januari 2000. Konflik Sosial Bernuansa Agama di Indonesia. Jakarta: Badan Litbang Agama dan Diklat Keagamaan Puslitbang Kehidupan Beragama Bagian Proyek Peningkatan Pengkajian Kerukunan Hidup Umat Beragama, h. 53-78 (2003)

[3] Muchtar, Ibnu Hasan.: Konflik-konflik sosial bernuansa agama, studi kasus kerusuhan Kupang Nusantara Timur (30 Nopember 1998). Konflik Sosial Bernuansa Agama di Indonesia. Jakarta: Badan Litbang Agama dan Diklat Keagamaan Puslitbang Kehidupan Beragama Bagian Proyek Peningkatan Pengkajian Kerukunan Hidup Umat Beragama, h. 107-134 (2003)

[4] Idham.: Proses dan Dinamika Konflik, Studi Tentang Konflik Identitas di Kecamatan Arelle, Tabulahan, danMambi (ATM) Sulawesi Barat. Disertasi. Program Pasca Sarjana Universitas Negeri Makassar (2003)..

[5] Surur, Umar.: Konflik sosial, bernuansa SARA berbagai komunitas etnik di Kalimantan Barat". Konflik Sosial Bernuasa Agama di Indonesia. Jakarta: Badan Litbang Agama dan Diklat Keagamaan Puslitbang Kehidupan Beragama Bagian Proyek Peningkatan Pengkajian Kerukunan Hidup Umat Beragama, h. 25-52 (2003)

[6] Suseno, Franz, Magnis.: Pemikiran Karl Marx dari Sosialisme Utopiske Perselisihan Revisionisme. Gramedia Pustaka Utama, Jakarta (2003)

[7] Simmel, Georg.: Conflict The web of Group Affiliations. The Free Press, New York (1964)

[8] Coser, Lewis A.: The Function Of Social Conflict. The Free Press, New York (1996)

[9] Susan, Novi.: Sosiologi konflik \& isu-isu konflik kontemporer.: Kencana Prenada Media Group, Jakarta Timur (2009)

[10] Noman K. Denzin, Yvonna S. Lincon: Hand Book of Qualitative Research, diterjemahkan oleh Dariyatno dkk. Penerbit Pustaka Pelajar (2009)

[11] John W. Creswell: Qualitative Inquiry and Research Design Choosing Among Five Traditions. International Educational and Professional Publisher, Thousand Oaks London New Delhi (1997) 